\title{
Factors Affecting Mandatory Audit Rotation: Evidence from Jordan
}

\author{
Munther Al-Nimer ${ }^{1}$ \\ ${ }^{1}$ Accounting Department, Applied Science University, Jordan \\ Correspondence: Munther Al-Nimer, Accounting Department, Applied Science University, Jordan. E-mail: \\ M_nimer@asu.edu.jo
}

Received: March 10, 2015

Accepted: March 20, 2015

Online Published: May 25, 2015

doi:10.5539/ijef.v7n6p51

URL: http://dx.doi.org/10.5539/ijef.v7n6p51

\begin{abstract}
The study aims to examine the effect of specific contingency variables upon mandatory audit rotation represented by external auditor rotation, namely; audit independence, financial interests, audit Fees, and litigation from the perception of external auditors. The study contribution based on tackling debatable subject and its importance as most the studies examined the external auditor rotation as independent variable and attempted to find out its effect on audit quality through audit independence. In addition, by examine the effect from the external auditor's perception. In order to attain the study objectives the study utilized a questionnaire.

The study population consists from the Jordanian audit firms including big four audit firms and the sample will be selected randomly with taking into account comprising the big four. The study distributed 80 questionnaires, the returned and accepted for analyzing questionnaires were 52 questionnaires which gives $65 \%$ respond rate.

The study indicated that the following variables audit independence, financial interests, litigation have a significant impact on the external auditor rotation in the Jordanian audit firms. In addition, the study indicated that there is insignificant impact of audit fees variable upon external auditor rotation. As accumulated impact of all the examined variables the study revealed that there is significant impact between on factors influence of the audit and external auditor rotation. Finally, the study suggested carrying out more studies on this subject by tackling more variables which might affect audit rotation.
\end{abstract}

Keywords: mandatory audit rotation, audit quality, audit independence, audit fees, Jordan

\section{Introduction}

Mandatory audit rotation is one of the debatable subjects which have been examined by many researchers, and recently the studies of this topic emphasis on the impact of the mandatory audit rotation on audit quality, audit independence, and audit roles.

Firth et al. (2012) argued that many countries have implemented rules that require an audit partner to rotate off the audit of a specific client after a certain period of time in the belief that rotation will improve independence and will allow for a fresh look at the audit.

The concept of mandatory audit rotation of audit firms is statutory prescription of the length of time an audit firm stays and renders professional services to its clients. It requires audit firms to be rotated after a specific number of years despite the efficiency, quality, independence, trust and the willingness of the shareholders to keep the audit firm (Onwuchekwa et al., 2012). Despite that the concept of mandatory auditor rotation came in as a result of highly publicized corporate failures that resulted in litigations which explains that rotation of external auditors was conceived to be a solution to possible familiarity threat between members of the audit firm and the client.

Mandatory audit firm rotation has been proposed as a potential solution to the possibility that long auditor tenure may lead to a deterioration of audit quality. Therefore, Audit quality determinants are a focus of the accounting and auditing literature. Researchers have debated the effect of auditor rotation on audit quality over the last half-century. As a result many studies conducted, to find out the effect of external auditor rotation on audit quality such as, (Sanders et al., 2009; Firth et al., 2012; Zeff, 2003; Habib, 2011; Jennings et al., 2008; Kim \& Yi, 2009).

One the other hand, some studies linked the contemporary financial crisis to mandatory external auditor. Accordingly, this subject still a debatable topic in accounting filed as studies indicated that mandatory audit rotation would prevent auditors from becoming too close with managers, impacting on their independence and quality (Onwuchekwa et al., 2012). 
Chanterelle and Johnston (2013) suggest how it can be useful of regulators as they consider the implementation of mandatory rotation. The study indicated that the conclusions reached about the possible effectiveness of mandatory audit firm rotation appear to depend on the type of data used (voluntary vs. mandatory auditor changes), suggesting that regulators should exercise care when drawing inferences from past audit firm rotation research.

Additionally, it has been argued that audit quality is diminished with long audit tenure, that mandatory rotation will reduces familiarity threat, ensures auditors independence and provides a greater skepticism and a fresh perspective that may be lacking in long-standing auditor client relationships as a consequence external auditor rotation enables auditors to take a new assessment at client risk and engagement issues which might increasing auditor independence.

Nevertheless, the opponents of mandatory audit rotation suggest that a loss of client knowledge when the auditor is forced to resign will ensure as auditors experience a significant learning curve with new clients (Knapp, 1991). Audit failures are generally higher in the first years of the auditor-client relationship as the new auditor understands the client's operations (Arel, Brody, \& Pany, 2005).

As a result most of the studies examine the effect of external auditor rotation on the independence or on the audit quality; therefore, the current study will examine the external auditor rotation as dependent variable by examining factors which might affect eternal auditor rotation from the auditor perception.

\subsection{Objective of the Study}

The current study will examine the effect of specific contingency variables upon mandatory audit rotation represented by external auditor rotation, namely; audit independence, financial interests, audit Fees, and litigation from the perception of external auditors.

\subsection{Research Question}

According to the study objective, the current study will attempt to answer the following questions:

1) Does audit independence affect the external auditor rotation?

2) Does Financial Interests affect the external auditor rotation?

3) Does Audit Fees affect the external auditor rotation?

4) Does Litigation affect the external auditor rotation?

\subsection{Significant of the Study}

After reviewing the relevant literature concerning external auditor rotation, the study will be significant and tackling debatable subject and the following are the most importance of the study:

1) Most of the studies examined the external auditor rotation as independent variable and attempted to find out its effect on audit quality through audit independence.

2) One of the suggested reasons behind the recent financial crisis were the quality of audit services which effected directly by audit rotation.

3) The current study will examine the effect from the external auditors perception.

\section{Literature Review and Hypotheses Development}

Kalsom and Hazlina (2014) indicated that the Non-Big Four audit firms issued more qualified opinion. The association between reputable audit firm and the rotation of mandatory audit partner seemed significant in a study conducted in Malaysia to analyze the different types of audit report and audit rotation.

A study conducted by Sati P et al. (2014) in order to examines the audit quality consequences of China's mandatory audit partner rotation (MPR) regulation, which became effective in 2004 . The study revealed that audit quality improves in the three years immediately following a client firm's MPR during the 2004-2011 periods for a sample of 273 Chinese publicly listed firms. The study highlighted that the improvement is most pronounced in those Chinese provinces with both low levels of audit market concentration and low levels of legal development .

Firth et al. (2012) argued that the Enron/Arthur Andersen scandal has raised concerns internationally about auditor independence, audit quality, and the need for regulatory action such as mandatory auditor rotation. In a study examined the effect of auditor rotation on audit quality and indicated that voluntary audit firm rotation although the significance level is much weaker than for mandatory partner rotation. Other forms of auditor rotations (i.e., mandatory audit firm rotation and voluntary audit partner rotation), have no effect on modified audit opinion.

Bobbie and Quinton (2011) attempted to explore loan officers' perceptions of auditors' independence and audit 
quality under three experimental audit firm rotation scenarios. The study indicated that loan officers do perceive an increase in independence when the company follows an audit firm rotation policy. However, the length of auditor tenure within rotation fails to significantly change loan officers' perceptions of independence. Findings also indicate that neither the presence of a rotation policy nor the length of the auditor tenure within rotation significantly influences the loan officers' perceptions of audit quality.

On the other side a study conducted by Lu and Sivaramakrishnan (2009) to investigate the effects of mandatory audit firm rotation on companies' investment decision and auditor choice in a capital market setting. The study found that when firms engage in opinion shopping, mandatory audit firm rotation improves investment efficiency for some firms but impairs investment efficiency for other firms.

Blandón and Bosch (2013) Pointed that in 2010 Green Paper on Audit Policy by the European Commission has explicitly questioned the sufficiency of audit rotation rules established by European Union Members to guarantee auditor independence. In a study conducted to examine the effects of audit firm tenure on independence. Therefore, the study shown that there was not any significant effect of tenure on the opinion of the audit report.

Kouaib and Jarboui (2014) in a study examined the relation between external audit quality and ownership structure by using jointly external audit quality and ownership structure over managerial discretion in a largely unexplored, non-Western and emerging context. The study revealed that auditor reputation has a negative and significant effect on earnings management. In addition, revealed that there was effect of external audit quality variables and capital concentration on earnings management and the cross effect of this combined relation is negatively and significantly associated with earnings management of industrial firms but it has no significant effect on the earnings management of commercial firms .

Barbara et al. (2006) attempted to find out the Effects of Audit Firm Rotation on the Audit Process and indicated that auditors in the rotation condition are more likely to modify their audit report as contrasted to those in a situation in which a continuing relationship is expected.

Chi and Huang (2005) examined how audit tenure affects earnings quality by investigating the effect of audit-firm and audit-partner tenure on the level of discretionary accruals. The study indicated that familiarity helps to produce higher earnings quality, but excessive familiarity results in lower earnings quality. Besides, Big 5 auditors are superior in obtaining learning experience in the initial period of engagement, which implies that the negative effect on earnings quality is more serious for clients of non-Big 5 auditors if audit-firm rotation is mandated.

A study conducted to examine the relation between auditor rotation and the appearance of independence and indicated that no statistically significant difference in beliefs about how much of an income reducing audit difference management will record, or in beliefs about auditor independence, between the two auditor rotation conditions. On the other hand, we find that non-professional investors do believe more of the audit difference will be recorded, and the auditors will be more independent, under a strong audit committee than a relatively weak audit committee. The second experiment provides further evidence on audit firm versus partner rotation by examining a setting involving a 26-year audit firm-client relationship. Again, no statistically significant differences between the two auditor rotation conditions were found. (Kaplan \& Mauldin, 2008).

Tagesson et al. (2006) debated that Auditor independence is considered a key factor when ensuring high audit quality. Advocates for auditor rotation argue that rotation improves audit quality due to its positive influence on auditor independence. Opponents argue that rotation does not lead to improved audit quality, in a study and indicated that only weak support for the hypothesis that rotation influence audit quality. The weakness is partly due to measurement problems. In addition, they suggested that two main facets, perceived audit quality, which is significantly influenced by auditor rotation, and actual audit quality, which is not influenced by rotation. Benito and Paz-Ares (1997) examined the relation between Mandatory rotation and audit quality by analyzing the effect of requirement on audit cost and quality. The rule is shown to increase audit cost and price through the destruction of specific assets and the distortion of competition. The study indicated a negative impact on quality is also a highly plausible effect, as a consequence of the lower technical competence of auditors and fewer incentives for independent behavior-at least for diversified auditors.

According the preceding literature reviews most of the related literature concerning audit rotation, the studies focused on the effect of the audit rotation on many aspects of audit, mainly; audit quality, audit independence, qualified opinion, audit procedures and indicated that there is significant influence of the audit rotation on these variables, therefore, the current study will attempt to find out the converse effect by examine the effect of these variables on external auditor rotation in the Jordan. The following are the formula of the study theoretical study theoretical Framework followed by hypothesis of the study. 


\subsection{Study Theoretical Framework}

\section{Independent variables}

Audit independence

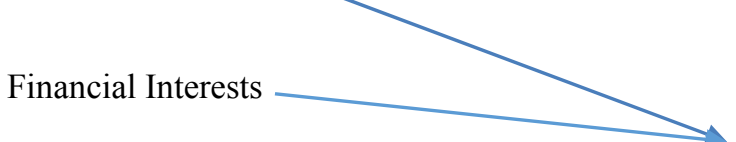

Audit Fees

Litigation

\subsection{Hypothesis of the Study}

For the purpose of the current study and based on the relevant literature, the hypothesis is formulated in null form external auditor rotation.

\subsubsection{The Main Hypothesis}

H0: There is no impact between on Factors Influence of the audit and external auditor rotation.

\subsubsection{The Sub-Hypothesis}

H0:1: There is no impact between on the independence of the audit and external auditor rotation.

H0:2: There is no impact between on Financial Interests of the audit and external auditor rotation.

H0:3: There is no impact between on Audit Fees of the audit and external auditor rotation.

H0:4: There is no impact between on Litigation of the audit and external auditor rotation.

\section{Study Methodology}

The object of this study is to examine the impact of contingency variables upon external auditor rotation in Jordan. In order to achieve this objective the study will utilize a questionnaire as research collection method. The questionnaire will be entitled to the study respondents which represented by audit firms in Jordan. The study will distribute the questionnaire by handing the respondents y their copy in order to increase the respond rate and to cope with the Jordanian respondent's culture. The questionnaire will consist from three main sections; first section will design to collect general information regarding the auditors characters, second section will attempt to find out their perception regarding audit rotation and the last section will includes questions regarding gathering data concerning their perceptions of contingency variables. The data that will be collected will analyze utilizing tables and percentages. In order to testing the study hypothesis, the study will unitize simple and multiple regression technique.

\subsection{Study Population and Sample}

The study population consists from the Jordanian audit firms including big four audit firms and the sample will be selected randomly with taking into account comprising the big four. The study distributed 80 questionnaires, the returned and accepted for analyzing questionnaires were 52 questionnaires which gives $65 \%$ respond rate. The following table summarized the presented of returned questionnaires as shown in table No. 1 below.

Table 1. Study sample

\begin{tabular}{lll}
\hline \multicolumn{1}{c}{ Item } & Frequency & Percentage \\
\hline Big Four Company & 26 & $50 \%$ \\
Non Big Four Company & 26 & $50 \%$ \\
\hline
\end{tabular}

\section{Analysis and Finding Discussion}

\subsection{Demographic Analysis of the Study}

After gathering the data of the study, and built on what has been based upon the previous quarter of statistical methods, data were collected to draw conclusions for companies sample analysis, and includes this chapter on the three main sections, respect to the first section analysis of descriptive variables study utilizing several measures of statistical and descriptive Alost arithmetic standard deviation and the highest value and the lowest value. The 
second section is related to the verification of the data for statistical analysis has expired, and the last section is to test hypotheses using simple regression model and discuss the results. As shown in table No. 2 below.

Table 2. Demographic results

\begin{tabular}{lcc}
\hline \multicolumn{1}{c}{ Percentage } & Qualifications & \\
\hline Bachelor & Frequency & Item \\
Masters & 49 & $94.20 \%$ \\
& 3 & $5.80 \%$ \\
Accounting & Specialization & \\
Another specialization field & 44 & $84.60 \%$ \\
& 8 & $15.40 \%$ \\
Less Than 5 years & Experience & \\
From 5-10 & 32 & $61.50 \%$ \\
From 11-15 & 17 & $32.70 \%$ \\
& 3 & $5.80 \%$ \\
Up to 50 & No. of Employees & \\
Above 50 & 29 & $55.80 \%$ \\
& 23 & $44.20 \%$ \\
ACPA & 2 & \\
CPA & 9 & $3.80 \%$ \\
Another Identified & 7 & $17.30 \%$ \\
There is no & 34 & $13.50 \%$ \\
\hline
\end{tabular}

Table 2 above indicated to the high educated audit firm's staff and that influence the quality of audit services and the high level of awareness the employees of this firms.

Moreover, there is a reasonable indication of the staff to develop their education level by taken higher education. The result of specialization of the audit firms question indicated that almost $85 \%$ of the staff is specialized in accounting which gives them a high level of service quality and they have an applicable accounting background for processing audit services. The respondent's answers regarding their relevant experience in audit services indicated that almost $90 \%$ of the staff has at least 5 years' experience in audit field which provide them a decent opportunity to participate in different issues and give them more knowledge and skills. The table above indicated that audit firms in Jordan are small and medium size firms based on the number of employee were recruited.

Additionally, with respect to professional certification campaign there is $65 \%$ of respondents haven't possess professional certificates and $35 \%$ of them have possess professional certificates which gives a reasonable indication of the awareness of importance of these certificates in the practical life specially certificates related to audit field.

\subsection{Reliability Statistics Test for Questionnaire}

Table 3. Reliability test

\begin{tabular}{lccc}
\hline \multicolumn{1}{c}{ Title } & No. of Questions & Reliability & Validity \\
\hline Opinion regarding auditor rotation & 5 & 0.744 & 0.863 \\
The Effect of audit independence on Auditor Rotation & 14 & 0.942 & 0.971 \\
The Impact of the Financial Interests on Auditor Rotation & 6 & 0.882 & 0.939 \\
The Impact of Audit Fees on Audit Rotation & 4 & 0.915 & 0.957 \\
The Effect Litigation on Auditor Rotation & 7 & 0.913 & 0.956 \\
Total & 36 & 0.92 & 0.959 \\
\hline
\end{tabular}

The reliability essential elements of a questionnaire tested by practical application by a group of experts chosen by the researcher in order to ensure racial stability and honesty in the questionnaire provide.

Therefore, where reliability coefficient (Reliability) the stability of the scale, non-contradiction with itself, that is, it gives the same results if re-applied to the same sample, while the mean honesty coefficient (Validity) that the 
scale measures what has been developed to measure. To test reliability and honesty questions answers of the questionnaire was used Cranach's coefficient alpha (Cranach's Alpha) has reached the value of Cranach's alpha as follows: Table 3.

Notes from the above Table 3 that the alpha coefficient ratios indicate that there is a high degree of stability for the resolution of all questions, where alpha coefficient was statistically acceptable to all the constituent elements of the questionnaire and to the fact that such transactions is higher than $(60 \%)$.

\subsection{Test Hypotheses and Result Discussion}

In order to achieve the study objectives the following section will represent the study hypothesis, preliminary the result of testing the individual independent variables with external audit rotation as dependent variable as shown below then determine the accumulated effect of all the independent variables on the depend variables.

\subsubsection{Descriptive Analysis of the Contingency Variables}

As show in table No. 4 below, the respondents were ranked the contingency variables and the answers indicated that financial interest consider as the most expected to effect the audit rotation followed by litigation variable , then audit independence. Moreover, the study revealed that audit service fees ranked to be the less variable which effect audit rotation.

Table 4. Contingency variables

\begin{tabular}{lcc}
\hline \multicolumn{1}{c}{ Contingency variables } & mean & S-deviation \\
\hline The Impact of Audit Fees on Audit Rotation & 3.53 & 0.947 \\
The Effect of audit independence on Auditor Rotation & 3.72 & 0.804 \\
The Effect Litigation on Auditor Rotation & 3.81 & 0.831 \\
The Impact of the Financial Interests on Auditor Rotation & 3.89 & 0.713 \\
\hline
\end{tabular}

H0:1: There is no impact between on the independence of the audit and the external auditor rotation.

Table 5. Independence and external auditor rotation.

\begin{tabular}{ccccc}
\hline Sig & t- statistics & Coefficients & Constant B & audit independency B \\
\hline 0.039 & 6.894 & -0.288 & 2.679 & -0.217 \\
Adjusted R Square & & 0.064 & \\
Model F test & & 4.507 & \\
\hline
\end{tabular}

Table displays (5) revealed the results of independence variable regression analysis and its impact on the external auditor rotation, The results showed that the value of (T TEST) calculated is greater than the value of (T tables), addition shows that the value of $(\operatorname{sig}>5 \%)$, which means that the independency affect the external auditor rotation, to be noted during the review of this table above that the coefficient of determination Adjusted R Square reached (0.064) which means that the external auditor rotation explain this rate of change independency.

H0:2: There is no impact between on Financial Interests of the audit and external auditor rotation.

Table 6. Inancial interests and external auditor rotation

\begin{tabular}{ccccc}
\hline Sig & $\mathrm{t}$ - statistics & Coefficients & Constant B & Financial Interests B \\
\hline 0.031 & 6.356 & -0.302 & 2.879 & -0.254 \\
Adjusted R Square & \multicolumn{2}{c}{0.073} & & \\
Model F test & \multicolumn{2}{c}{4.926} & & \\
\hline
\end{tabular}

Table 6 displays the results of Financial Interests variable regression analysis and its impact on the external auditor rotation), The results showed that the value of (T TEST) calculated is greater than the value of (T tables), addition shows that the value of $(\mathrm{sig}>5 \%)$, and accordingly reject the hypothesis Ho, which means that the Financial Interests affects the external auditor rotation, as the Adjusted R Square reached (0.073) which means that the external auditor rotation explain this rate of change Financial Interests. 
H0:3: There is no impact between on Audit Fees of the audit and external auditor rotation.

Table 7. Audit fees and external auditor rotation

\begin{tabular}{ccccc}
\hline Sig & t- statistics & Coefficients & Constant B & Audit Fees B \\
\hline 0.360 & 6.653 & -0.131 & 2.183 & -0.083 \\
Adjusted R Square & & & -0.003 & \\
Model F test & & & 0.855 & \\
\hline
\end{tabular}

Table 7 displays the results of Audit Fees variable regression analysis and its impact on the external auditor rotation, The results showed that the value of (T TEST) calculated is greater than the value of (T tables), addition shows that the value of ( $\operatorname{sig}>5 \%$ ), depending on the decision rule which states accept the hypothesis Ho if the calculated $t$ value is less than the tabular value was the moral value sig greater than 0.05 , which there is no impact for the audit fees on the external auditor rotation.

H0:4: There is no impact between on Litigation of the audit and external auditor rotation.

Table 8. Litigation and external auditor rotation

\begin{tabular}{ccccc}
\hline Sig & t- statistics & Coefficients & Constant B & Litigation B \\
\hline 0.015 & 7.464 & -0.339 & 2.821 & -0.245 \\
Adjusted R Square & & 0.097 & \\
Model F test & & 6.353 & \\
\hline
\end{tabular}

Table 8 displays the results of Litigation variable regression analysis and its impact on the external auditor rotation, The results showed that the value of (T TEST) calculated is greater than the value of (T tables), addition shows that the value of ( $\operatorname{sig}>5 \%$ ), which means that the Litigation affects the external auditor rotation, to be noted during the review of this table that the coefficient of determination Adjusted R Square reached (0.097) which means that the external auditor rotation explain this rate of change Litigation.

H0: There is no impact between on Factors Influence of the audit and external auditor rotation.

Table 9. Contingency variables and external auditor rotation

\begin{tabular}{|c|c|c|c|c|c|c|c|}
\hline \multicolumn{8}{|c|}{ Model Summary } \\
\hline Model & $\mathrm{R}$ & R Square & \multicolumn{2}{|c|}{ Adjusted R Square } & \multicolumn{3}{|c|}{ Std. Error of the Estimate } \\
\hline 1 & $.412^{\mathrm{a}}$ & .170 & \multicolumn{2}{|c|}{.098} & \multicolumn{3}{|c|}{.57004} \\
\hline \multicolumn{8}{|c|}{ a. Predictors: (Constant), Independence, Financial Interests , Audit Fees, , Litigation } \\
\hline \multicolumn{8}{|c|}{ ANOVA $^{b}$} \\
\hline & Model & \multicolumn{2}{|c|}{ Sum of Squares } & $\mathrm{df}$ & Mean Square & $\mathrm{F}$ & Sig. \\
\hline & Regression & \multicolumn{2}{|c|}{3.065} & 4 & .766 & 2.358 & $.042^{\mathrm{a}}$ \\
\hline & Residual & \multicolumn{2}{|c|}{14.948} & 46 & .325 & & \\
\hline & Total & \multicolumn{2}{|c|}{18.012} & 50 & & & \\
\hline
\end{tabular}

a. Predictors: (Constant), Seq6, Seq4, Seq5, Seq3

b. Dependent Variable: Seq2

\begin{tabular}{|c|c|c|c|c|c|}
\hline \multicolumn{6}{|c|}{ Coefficients $^{\mathrm{a}}$} \\
\hline \multirow{2}{*}{ Model } & \multicolumn{2}{|c|}{ Unstandardized Coefficients } & \multirow{2}{*}{$\begin{array}{l}\text { Standardized Coefficients } \\
\text { Beta }\end{array}$} & \multirow{2}{*}{$\mathrm{t}$} & \multirow{2}{*}{ Sig. } \\
\hline & B & Std. Error & & & \\
\hline (Constant) & 3.094 & .461 & & 6.715 & .000 \\
\hline Independence & -.077 & .292 & -.105 & -.265 & .022 \\
\hline Financial Interests & -.208 & .175 & -.247 & -1.190 & .240 \\
\hline Audit Fees & .227 & .156 & .358 & 1.455 & .152 \\
\hline
\end{tabular}




\begin{tabular}{cccccc}
\hline Litigation & -.239 & .215 & -.331 & -1.114 & .271 \\
a. Dependent Variable: Seq2 & & & & & \\
\hline
\end{tabular}

After discussing the sub-hypotheses given in Table 9 as the value $\operatorname{sig}(42 \%<5 \%)$ the hypothesis has been rejected the first main Hypothesis and this means that there is impact between on Factors Influence of the audit and external auditor rotation. It is worth mentioning that multiple regression analysis has shown that the factor analysis adjusted R Square (0.170) which means that the external auditor rotation explain the change in these Factors Influence.

\section{Study Conclusion}

Based on the study objective which emphasis on examining the effect of specific variables mainly; audit independence, financial Interests, audit fees, and litigation on the audit rotation from the perception of external auditors. The study indicated that the following variables audit independence, financial interests, litigation have a significant impact on the external auditor rotation in the Jordanian audit firms. In addition, the study indicated that there is insignificant impact of audit fees variable upon external auditor rotation. As accumulated impact of all the examined variables the study revealed that there is significant impact between on factors influence of the audit and external auditor rotation. The study support the preceding literature which examine the impact of these variables and audit rotation but from the perception of external auditors and examined the reverse impact as most the literature examined the audit rotation as independent variable and the current study examined it as depend variable . Accordingly, the study suggested carrying out more studies on this subject by tackling more variables which might affect audit rotation.

\section{Acknowledgements}

The Author is grateful to the Applied Science Private University, Amman, Jordan, for the full financial support granted to this research project (Grant No. DRGS-2014-2015-62).

\section{References}

Ahsan, H. (2009). Audit firm industry specialization and audit outcomes: Insights from academic literature. Journal of Accounting and Public Policy, 28(3), 207-230.

Amel, K., \& Anis, J. (2014). External Audit Quality and Ownership Structure: Interaction and Impact on Earnings Management of Industrial and Commercial Tunisian Sectors. Journal of Economics Finance and Administrative Science, 19(37), 78-89. http://dx.doi.org/10.1016/j.jefas.2014.10.001

Arel, B., Brody, R. G., \& Pany, K. (2005). Audit firm rotation and audit quality. CPA Journal.

Andrew, B., Jackson, M. M., \& Peter, R. (2008). Mandatory Audit Firm Rotation and Audit Quality. Managerial Auditing Journal, 23(5).

Arruñada, B., \& Cándido, P. A. (1997). Mandatory Rotation of Company Auditors: A Critical Examination. International Review of Law and Economics, $17(1), \quad 31-61$. http://dx.doi.org/10.1016/S0144-8188(96)00063-4

Barbara, A., Richard, B., \& Kurt, P. (2006). Findings on the Effects of Audit Firm Rotation on the Audit Process under Varying Strengths of Corporate Governance. Advances in Accounting, 22, 1-27. http://dx.doi.org/10.1016/S0882-6110(06)22001-7

Bobbie, W. D. (2011). Quinton Booker, The effects of audit firm rotation on perceived auditor independence and audit quality. Research in Accounting Regulation, 23(1), 78-82. http://dx.doi.org/10.1016/j.racreg.2011.03.008

Buck, T., \& Michaels, A. (2005). Doubts Cast on Mandatory Rotation of Auditors. London: Financial Times Publisher.

Christina, B. S., Michelle, D. S., \& Sheri, B. (2009). Facilitating knowledge transfer during SOX-mandated audit partner rotation. Business Horizons, 52(6), 573-582. http://dx.doi.org/10.1016/j.bushor.2009.07.004

Jeffrey, R. C., \& Derek, J. (2013). Can the academic literature contribute to the debate over mandatory audit firm rotation? Research in Accounting Regulation, $108-116$. http://dx.doi.org/10.1016/j.racreg.2012.11.004

Kim, J. B., \& Yi, C. H. (2011). Does Auditor Designation by the Regulatory Authority Improve Audit Quality? Evidence from Korea. Research in Accounting Regulation, 23(2), 114-129. 
John, C. O., Dominic, O. E., \& Famous, I. (2012). Mandatory Audit Rotation and Audit Quality: Survey of Southern Nigeria. Research Journal of Finance and Accounting, 3(8).

Josep, G. B., \& Josep, M. A. B. (2013). Audit Firm Tenure and Qualified Opinions: New evidence from Spain. Revista de Contabilidad, 16(2), 118-125. http://dx.doi.org/10.1016/j.rcsar.2013.02.001

Kalsom, S., \& Hazlina, J. (2014). Audit Rotation and Audit Report: Empirical Evidence from Malaysian PLCs over the Period of Ten Years. Procedia-Social and Behavioral Sciences, 145(25), 40-50.

Knapp, M. (1991). Factors that Audit Committees Use as Surrogates for Audit Quality. Auditing: A Journal of Practice \& Theory, 10(1), 35-52.

Marianne, M., Jennings, K. P., \& Philip, M. J. R. (2008). Internal control audits: Judges' perceptions of the credibility of the financial reporting process and likely auditor liability. Advances in Accounting, 24(2), 182-190. http://dx.doi.org/10.1016/j.adiac.2008.08.006

Michael, A. F., Oliver, M. R., \& Xi, W. (2012). Rotate back or Not After Mandatory Audit Partner Rotation? Journal of Accounting and Public Policy, 31(4), 356-373. http://dx.doi.org/10.1016/j.jaccpubpol.2012.05.002

Michael, F., Oliver, M. R., \& Xi, W. (2012). How Do Various Forms of Auditor Rotation Affect Audit Quality. The International Journal of Accounting, 47(1), 109-138. http://dx.doi.org/10.1016/j.intacc.2011.12.006

Sati, P. B., Chen, C., \& Yu, Y. (2014). Mandatory audit partner rotation, audit market concentration, and audit quality: Evidence from China. Advances in Accounting, 30(1), 18-31. http://dx.doi.org/10.1016/j.adiac.2013.12.001

Steven, E. K., \& Elaine, G. M. (2008). Auditor rotation and the appearance of independence: Evidence from non-professional Investors. Journal of Accounting and Public Policy, 27(2), 177-192. http://dx.doi.org/10.1016/j.jaccpubpol.2008.01.004

Stephen, A. Z., \& Pont's, U. (2003). Early Policy on the Rotation of Audit Firms. Journal of Accounting and Public Policy, 22(1), 1-18. http://dx.doi.org/10.1016/S0278-4254(02)00083-2

Tong Lu, K. S. (2009). Mandatory audit firm rotation: Fresh look versus poor knowledge. Journal of Accounting and Public Policy, 28(2), 71-91. http://dx.doi.org/10.1016/j.jaccpubpol.2009.01.006

Torbjörn, T., \& Linus, S., Collin, S., Hanna, O., \& Johan, S. (2006). Does Auditor Rotation Influence Audit Quality: The Contested Hypotheses tested on Swedish Data. Working Paper Series 2006:4 Department of Business Studies. Kristianstad University College, Sweden.

Chi, W., \& Huang, H. (2005). Discretionary Accruals, Audit-Firm Tenure and Auditor Tenure: An Empirical Case in Taiwan. Journal of Contemporary Accounting \& Economic, 1(1), 65-92. http://dx.doi.org/10.1016/S1815-5669(10)70003-5

\section{Copyrights}

Copyright for this article is retained by the author(s), with first publication rights granted to the journal.

This is an open-access article distributed under the terms and conditions of the Creative Commons Attribution license (http://creativecommons.org/licenses/by/3.0/). 